Daniela Gračan *

Zrinka Zadel ${ }^{* *}$

Damir Pavlović ****
JEL Classification: Z32, Z33

Preliminary statement

https://doi.org/10.32910/ep.72.2.2

\title{
MANAGEMENT OF VISITOR SATISFACTION BY USING MOBILE DIGITAL TOOLS AND SERVICES TO CREATE CONCEPT OF SMART DESTINATION
}

Tourism is a system that inevitably follows the technological advancement of other areas of social and economic life, especially in the domain of accessibility of all elements of tourist product offered by its basic unit - a tourist destination. Due to the inclination and the need to use mobile digital tools and services for visitors to better manage, the concept of the so-called "smart destination" is becoming increasingly important. However, as digital applications become increasingly saturated with everyday life and threaten the saturation of real and quality life, there is a need for selective access also in the domain of destination management through experience management and visitor satisfaction.

Using the methodology of the survey questionnaire a survey has conducted on several tourist frequency locations in the destination, whose aim was to investigate the importance and participation of individual mobile applications in improving the visitor experience, among them the five most prominent. By applying correlation and regression analysis, results have been achieved, which applications most importantly participate in improv-

* D. Gračan, PhD, full professor, University of Rijeka, Faculty of Tourism and Hospitality Management (e-mail: danielag@fthm.hr).

** Z. Zadel, PhD, associate professor, University of Rijeka, Faculty of Tourism and Hospitality Management (e-mail: zrinka.zadel@fthm.hr).

*** D. Pavlović, PhD, Senior Lecturer, Libertas International University (e-mail: damir. pavlovic@zg.t-com.hr). The paper was received on 03.12.2018. It was accepted for publication on 01.04.2019. This paper was founded under the project line ZIP UNIRI of the University of Rijeka, for the project ZIP-UNIRI-116-1-20. 
ing the visitor experience. The significance of this research is reflected in the design of a new tool for adaptive and selective introduction of new mobile applications in order to better target visitors in a destination and thus more effectively manage their experience.

Keywords: smart destination, mobile apps, visitor satisfaction and experience, regression analysis

\section{INTRODUCTION}

Tourism, as an important factor of economic development, is undergoing significant changes, primarily due to changes in the habits of tourists who require innovative experiences of traveling and staying in a particular destination in accordance with their own affinities and preferences. Accordingly, there is an increasing individualization and differentiation of their needs, which require an individualized approach to their satisfaction by the destination suppliers. However, there is something in common with all stakeholders, namely the formation and use of digital applications with the purpose of providing promptly all the necessary information for planning the whole trip with an emphasis on staying in the destination (easier access and managing through smart maps, accommodation and transportation booking, contacting others and sharing their own experiences, etc.). In accordance with the aforementioned behavioral trend and visitors' requests, the destinations are beginning to implement the so-called "smart tourist services" that want to position and be recognizable as a smart tourist destination. Despite the recognition of the impact of technology on tourism experience, only a few studies focused on the impact of a smart destination strategy on tourism experience (Neuhofer et al., 2012; Presenza et al., 2014; Boes et al., 2015; Buonincontri $\&$ Micera, 2016). Basically, they were based on qualitative research, using website data, public documentation, or deep interviews with destination managers. However, in order to achieve progress in the research, some empirical research should be included in additional destinations, thus gaining confidence and the external validity of the research.

Therefore, this paper aims to contribute to the debate on tourism innovations, proposing a framework that assesses how mobile applications used in the destination can, on the one hand, collectively and individually improve the tourist experience, and on the other hand, detect any negative impacts and difficulties in their implementation in the destination. In practical terms, such situational analyzes can also be useful for destination managers to design an adequate visitor's satisfaction management strategy at the destination. 
From the above, several research objectives (RO) are imposed, most important of which are:

$\mathrm{RO}_{1}$ - Determine the correlation (relationship) between total tourist satisfaction when visiting a smart destination and the use of mobile apps that are available for that purpose.

$\mathrm{RO}_{2}$ - Identify which mobile applications are most dominant in the tourist experience of visitors / tourists in a smart destination.

$\mathrm{RO}_{3}$ - Identify whether there are any possible negative circumstances in using mobile applications in function of tourist visit to a smart destination.

This study is structured according to the standard form of scientific paper. After reviewing the literature, a chapter explains the description of some mobile applications intended for visitors, so that, when interpreting the results of the research, it becomes easier to understand their individual importance for the destination experience. The methodology chapter presents: a survey sample (within the Zagreb destination) and a research approach; quantitative (regression analysis) in combination with qualitative analysis (interviews with relevant experts who are directly related to the subject project). Thereafter, it follows the chapter in which are the results of the research with the discussion and limitations of the same research, and a recommendation for future research.

Conclusion, in response to research questions, speaks of the contribution of research and the perspective of analyzing the case and assessing the tourist experience in the function of destination management.

\section{LITERATURE REVIEW}

A review of literature has highlighted the importance of using technology in tourist destinations to be classified as smart, and hence confirmed as a competitive destination, which promotes tourism experience by using mobile technology in different moments and situations arising from travel. Literature on tourism experiences shows that the competitiveness of the destination increases when there is interaction between tourists and what the destination offers by using new technologies (Neuhofer et al., 2012). It is especially important to emphasize, in this context, the revolution in mobile technology with the special role of smartphones, which in many occasions serve as travel support (Wang et al., 2012). Expected advances in mobile technologies and increased / virtual reality can further shift the boundaries of data collection and usage in the overall visitor experience. This technological 
advancement does not have so much effect on the individual level but through connectivity, synchronization and the harmonized use of various technologies that together form a collective intelligence (Gretzel et al., 2015a).

Technological advances have influenced how we live in society (Dieck \& Jung, 2018). ICT can help make the destination more accessible and appealing to both residents and visitors, as it contributes to the development of interactive services linking local organizations, allowing users quick access to necessary data and services (Liberato at al., 2018). The concept of smart destination is applied to destinations where technology affects tourism experience, enhances its competitiveness and promotes development projects in tourism (Boes et al., 2015; Presenza et al., 2014).

Modern tourists want to be positively surprised by an unknown destination and need information about what to do, what to visit and how to get to the place using technology. In this respect, technology integrates global destinational experience (Wethner et al., 2015). So, a tourist destination should become the destination of emotions and experiences in the context of a smart destination. Based on this approach, tourists interactively colaborate with service providers in creating their own experiences, thus directly contributing to the creation of innovations (Buhalis \& Amaranggana, 2014).

Despite the fact that the implementation of smart tourism in cities and destinations is becoming more emphesized, it is possible to notice that it is not adequately documented, conceptualized, critically analyzed and discussed in the literature. It is therefore necessary to present and analyze additional practices arising from the use of smart tourism in cities as a confirmation that smart tourism is a new platform for innovation, creativity and competitiveness in tourist destinations.

The results of this study will explain in a critical way the relationship between the use of some mobile applications and the overall satisfaction of visitors, or the improvement of their tourist experience.

\section{OVERVIEW OF MOBILE APPLICATIONS IN FUNCTION OF TOURIST VISIT TO A SMART DESTINATION}

For the purpose of this paper, research on the example of the City of Zagreb was conducted as a smart destination. The Zagreb Tourist Board is one of the first in Europe to begin the presentation of Zagreb tourist sites via QR (Quick Response) codes. In the city of Zagreb, on the 28 city locations, QR codes have been set up, which, after being simply leaned by smartphone or other mobile device with the built-in android operating system, automatically provide pictures and video clips with all the necessary information about a number of tourist sites. 
Codes are placed in the wider city center, on pillars with brown (tourist) signaling, or signs for the most important city attractions. This is a continuation of the project given that the City of Zagreb has already got its unique QR code before the Tourist board initiative, and now they have them separately all tourist attractions. The code is now very well accepted. It is about a revolutionary and extremely practical way of presenting. It needs to have a valid mobile device with a free code-reader installed and search for attractions in the destination. The application of this code is diverse - i.e. it can quickly access to a desired web address, find an interactive map and other information, view photos and short video clips of each location.

One of the most significant mobile applications is Zagreb Be There. Developed as a game by which visitors visit certain locations and sign in to them. The application is based on so-called. gamification principle that rules and ways of interaction from computer games are projected to the real world. Upon completion of the selected route (offered by a total of five), visitors receive special awards and discounts when purchasing tickets for certain events or services at restaurants. Each of the offered routes represents Zagreb in a rather original and unusual way (eg, the offered route Space Zagreb offers a visit to all locations where there are art installations of sculptor Ivan Kožarić and Davor Preis representing grounded celestial bodies). The app is available on both Android and iPhone devices, and has been developed through game principles that change the rules and ways of interacting with video games in the real world. Once, the route is selected, tourists visit the locations with the help of the map, where they must sign up. After checking, one of the rewards can be unlocked at most locations, such as ticket discounts or bicycles with a two-in-one rental bid.

For the independent and unobstructed navigation of the destination with the help of the first voice guide, the Voice Guide Zagreb application was designed. It is an innovative solution with the use of innovative GPS technology for individual visitors, and is entirely a product of the domestic mind. When it comes to a place with tourist attractions, the application will be launched automatically to get information on nearby attractions. First, it is getting information about where the visitor is located, and then about other tourist attractions that can be visited nearby. It's about offline app, which means that once it's set up on a mobile device, no longer it requires internet access, it does not create additional costs for the user. The application is designed to provide a lot of other information and is always up-to-date, alongside offering sound records of all destination attractions. With a map of the destination and public transport, it contains a larger number of photos, information about opening time and ticket prices for museums or other similar facilities. With this application, users can learn about the best-known Croatian language phrases, inform about typical souvenirs and dishes, and suggest them the most important thing to see in the time they are available during a visit to the destination. Since the application contains 202 interesting short stories describing 
188 locations in the city and has an educational feature, apart from tourists, it may be of interest to city dwellers. Compared to other mobile mobile applications, this application is unique in that the audio tracks are automatically emitted to the user, and there is no need for his intervention, allowing them to unobtrusively visit and meet the locality. It is also an innovative way how a user can control the amount of information they receive automatically, because it will be enough to just shake the mobile device lightly and stop broadcasting the audio tracks of the current location. The app is adapted to work on multiple types of mobile devices and tablets based on Android or iOS operating systems. In closed areas where the GPS signal is unavailable, the application uses $\mathrm{QR}$ codes and thus provides a unique $\mathrm{QR}$ and GPS service, which is the first such solution in the world. Users who do not have GPS on their mobile devices can download the app from the QR Codes set in the destination and use it at least in a partially automated mode of operation. The user can also enter their own locations into the app so that they can later orient themselves and return to their places of interest

Greetings from Zagreb, the first mobile application was created at the National and University Library in Zagreb as a result of the long years work of the Library on digitalisation, the creation of digital libraries and virtual exhibitions systems. The application takes the user to a historic walk in the ten most attractive city locations, and along with walking reveals their past and can send personalized digital postcards and reveal more about Zagreb's spirit through other features that the app offers. Developed at the National and University Library in Zagreb, with the technical performance of the Blue Factory and with the support of the City of Zagreb Tourist Board, it is a unique cultural and tourist product that links old maps, postcards, photographs and knowledge of experts on cultural and historical heritage. The project Greetings from Zagreb has made as an innovative digital product that links tourism and cultural heritage and promotes the city's beauty recorded on postcards from the Graphic Collection of the National and University Library in Zagreb. Mobile application Greetings from Zagreb is easy to use and is also accompanied by an interesting portal of the same name. Once a user takes over the application, they can choose an old or new map of the city and walk around Zagreb exploring the ten most beautiful locations. You can send or share as many as 50 postcards with your family or friends. The application has been made so interesting to those who are not in Zagreb, because they can look at how the city changed in a unique blend of pictures Once and now, as well as in a gallery with 150 old postcards from the late 19th and early 20th centuries.

The Love Zagreb application shows a place where interesting Zagreb stories from local bloggers can be found, showing the city from a slightly different perspective compared to the main information pages of the city of Zagreb. The name is chosen because it follows the story of Zagreb as the City of One Million of Hearts - those real hearts that knock and those of the Licitar, which are the symbol 
of the city. Visitors can also participate in the content creation part - by uploading their own photos. By this application it wants to connect visitors with local people and customs who want to see how the city lives, that can not find in standard brochures and tourist guides.

The Spotted by Locals application delivers a variety of entertainment, hospitality and other contents of Zagreb together with 40 other European cities, but in a slightly different way. This application is a mobile travel guide with verified and daily updated information. Information is provided by selected bloggers, meaning that the local people who possess firsthand knowledge about their city. The app users on the screen can search for a detailed city map, find locations close to where they are, depending on their wishes and needs. Visitors can, before arriving in $\mathrm{Za}$ greb, find out which are the favorite places in Zagreb, where they are eating well, gathering various social groups, which are popular places to go and have fun, see and experience, and that are not particularly emphasized in the classic tourist offer.

The Zagreb gastronomic scene can be introduced with the Zagreb Food application, which gives an overview of restaurants and other gastronomic offerings in Zagreb. Focus is on new and interesting facilities for all those who want to enjoy the Zagreb food offer. The main function of the app is to view all objects on Google Maps that are displayed as pushpins. The user touches each object and gets basic information about the object. Mobile application Zagreb Food combines the culture of a city's life, world-famous gastronomy and modern technology into a design-friendly and functional totality.

\section{RESEARCH METHODOLOGY}

The purpose of this research is to assess the importance of the implementation of mobile technologies in the satisfaction and experience of tourists in a tourist destination. Quantitative analysis is selected in combination with qualitative analysis through interviews with relevant scientists directly related to the subject project. Zagreb has been chosen as a destination that is experiencing the rejuvenation stage in its life cycle, records year-over-year, double-digit growth rates of tourist traffic and is the new destination for most visitors. Consequently, there is a logical need to facilitate the stay especially for new and non-frequent visitors. Following the explanations from the previous chapters of this paper, the application of the concept of a smart tourist destination relying on mobile technology seems to be particularly suitable for the City of Zagreb and therefore relevant for the subject research. The reason for using the case study is based on its suitability as an ideal methodology in tourism (Gray \& Campbell, 2007) and in information systems when technology changes dynamics and when it is recently implemented (Pare, 2001). 
The survey questionnaire was used as a method of data collection and was compiled very briefly and simply in function of the efficiency and speed of its implementation. The structure of the questionnaire enabled data collection based on six variables; five independent, representing the degree of usefulness (contribution) of using each application in relation to the overall satisfaction level of the visit, which represents the dependent variable. Respondents (visitors) are asked to rank the usefulness of some mobile applications on the scale of one to five for the overall satisfaction level of their visit to the destination. The survey was conducted in five different places: Trg bana Jelačić; Upper Town; Kazališni trg; Zrinjevac; The railway station, which represents the areas with the highest concentration of tourists in the city. The survey was conducted in April 2018. The direct sampling method was used in the survey, where the selection of the sample is based on a criterion, in this case, for visitors using mobile applications in the function of their easier access to the city of Zagreb. So, the sample criterion represents the character of the respondent, namely, the fact that tourists are using mobile applications. Regardless of the fact that the results obtained from the sample can not be generalized throughout the population, the method of direct (non-probabilistic) sampling is particularly appropriate in cases where the sample is selected according to the disposability and availability of target population elements.

In the processing and analysis of the data, the correlation method (Pearson coefficient) was applied for the $\mathrm{RO}_{1}$, while the multiple regression analysis method was applied to $\mathrm{RO}_{2}$, in which the individual applications represented independent variables, and the overall degree of visitor satisfaction with their visit to the city was represented with dependent variable .

\section{RESEARCH RESULTS}

Compared to the socio-demographic profile of the respondents, the data collected show that the age group of the highest proportion of the sample belongs to the age group of 26 to 35 years, mostly of international origin (31\%), while more than half of the visitors are younger than 35 years old. Most visitors / tourists (68\%) visited the city for the first time and the main reason for their visit was cultural enthusiasm (26\%) followed by multi-traveler (19\%) and visiting relatives (16\%).

Research Objective (RO1) - Identifaying a correlation between the overall tourist satisfaction on the occasion of the visit to Zagreb and the use of mobile applications available to them for this purpose, the results of the questionnaire survey conducted on the respondents and the online data of users ranking of the applications were used. Preliminary analyzes were carried out to assure the assumptions of normality, linearity and homoscedasticity as well as the absence of 
too high collinearity of predictor variables, which could lead to non-objectivity of the final results of the regression analysis.

In the next step, correlations between predictor variables (some mobile applications) and criterion variables (total satisfaction with destination) were investigated and interrelated within predictor variables, thus gaining insight into the relative importance of individual predictors in the criterion variable and detecting possible inadequacy due to possible excessive co-existence within prediction variables (Tabachnick and Fidell, 2007). Table 5.1 shows the results of the descriptive statistics and the correlation matrix of observed variables included in the model.

Table 1

\section{DESCRIPTIVE STATISTICS AND CORRELATION OF VARIABLES INCLUDED IN THE MULTIPLE LINEAR REGRESSION MODEL}

\begin{tabular}{|l|c|c|c|c|c|c|c|c|c|}
\hline \multicolumn{1}{|c|}{ Variables } & N & M & SD & TE & ZBT & VGZ & LZ & GFZ & SBL \\
\hline Total experience (TE) & 25 & 3.142 & .4658 & - & & & & & \\
\hline Zagreb Be There (ZBT) & 25 & 3.346 & .9059 & $.470^{*}$ & - & & & & \\
\hline Voice Guide Zagreb (VGZ) & 25 & 3.274 & .5133 & $.736^{* * *}$ & $.445^{*}$ & - & & & \\
\hline Love Zagreb (LZ) & 25 & 2.914 & .8424 & $.777^{* * *}$ & $.824^{* * *}$ & $.676^{* * *}$ & - & & \\
\hline Greetings from Zagreb (GFZ) & 25 & 3.202 & .4125 & $.453^{*}$ & $.676^{* * *}$ & $.439^{*}$ & $.568^{* *}$ & - & \\
\hline Spotted by Lights (SBL) & 25 & 2.813 & .4530 & $.512^{*}$ & $.548^{* *}$ & $.486^{*}$ & $.491^{*}$ & $.538^{*}$ & - \\
\hline
\end{tabular}

Note: Statistical significance: $* \mathrm{p}<0,05 ; * * \mathrm{p}<0,01 ; * * * \mathrm{p}<0,001$

According to the indicators in Table 1.1, all correlations between total satisfaction (experience) by visiting the destination (TE) on one side and the use of some mobile applications, moderate to high, ranging between $\mathrm{r}=.453, \mathrm{p}<.05$ and $\mathrm{r}=.777, \mathrm{p}<0.001$. In the observed destination, there is a difference in the dominant correlation of prediction variables with respect to the criterion.

It is also apparent that mobile applications: Love Zagreb $(r=.777, \mathrm{p}<0.001)$ and Voice Guide Zagreb ( $\mathrm{r}=.736, \mathrm{p}<0.001)$ show a significantly greater correlation with overall satisfaction (Total experience) than other used mobile applications in the observed destination. By summing it up, it may lead to the conclusion that its content, usefulness, convenience and credibility are more appealing to visitors (users) than other observed applications. For example, the Voice Guide Zagreb application can serve as the surrogate of a hired personal tourist guide to get acquainted with all the major tourist attractions of the city of Zagreb, including practical advice and placement in the space. On the other hand, the Love Zagreb ap- 
plication, with a suggestive approach to the city through the personal stories of some bloggers, offers more personality in creating content (it can be created by visitors personaly) and therefore credibility in the perception of the users themselves.

In any case, all predictor variables (use of particular mobile applications) are statistically related to the degree of satisfaction with the visit to the Zagreb, and this relation is more significant in case of applications: Voice Guide Zagreb and Love Zagreb, which represents a positive response to $\mathrm{RO}_{1}$. This fact also indicated that the data was appropriately related to the criterion for the examination by multiple linear regression and thus obtained the conditions for seeking answers to the research objective:

$\mathrm{RO}_{2}$ - Identify which mobile applications are most dominant in the tourist experience of visitors / tourists in a smart destination.

In the implementation of linear regression using the SPSS software, the hierarchical method was applied as the most appropriate for the testing of the particular importance of individual predictor variables relative to the criterion variable (Field, 2009). The meaning of these methods is in the isolated introduction of individual predictors into the model, while others are kept under control (constant). The sequence of introducing variables in the model is controlled by previous theoretical settings (Beritelli, 2011). So this means that in a few steps (depending on the number of predictors), the model gained insight into the contribution of each individual predictor (added R2), i.e. its participation in the explanation of the criterion variable, in this case - total satisfaction (experience) by visiting the destination (TE). The results of the hierarchical regression analysis are shown in Table 2.

Table 2.

\section{REGRESSION MODEL OF TOTAL SATISFACTION WITH MOBILE APPLICATIONS IN THE DESTINATION OF ZAGREB}

\begin{tabular}{|l|c|c|c|c|c|c|c|c|c|}
\hline \multicolumn{1}{|c|}{ Variables } & $\mathrm{R}$ & $\mathrm{R}^{2}$ & $\begin{array}{c}\mathrm{R}^{2} \\
\text { Adjusted }\end{array}$ & $\begin{array}{c}\mathrm{R}^{2} \\
\text { Change }\end{array}$ & $\mathrm{B}$ & $\begin{array}{c}\mathrm{F} \\
\text { Change }\end{array}$ & $\beta$ & $\mathrm{sr}^{2}$ & $\mathrm{t}$ \\
\hline Total experience & .867 & .751 & .680 & & & 10.56 & & & \\
\hline Zagreb Be There (ZBT) & & & & .220 & -.276 & 12.83 & $-.337^{*}$ & .064 & -1.892 \\
\hline Voice Guide Zagreb (VGZ) & & & & .347 & .230 & 10.63 & $.480^{*}$ & .029 & 1.279 \\
\hline Love Zagreb (LZ) & & & & .273 & .534 & 4.81 & $.966^{*}$ & .183 & 3.208 \\
\hline $\begin{array}{l}\text { Greetings from Zagreb } \\
\text { (GFZ) }\end{array}$ & & & & .165 & 15.12 & .146 & .010 & .763 \\
\hline Spotted By Lights (SBL) & & & & .214 &. .348 & 28.93 & $.283^{* * *}$ & .084 & .961 \\
\hline
\end{tabular}

Note: Statistical significance: $* p<.05$; ** $p<.01 ; * * * p<.001$ 
The final model showed statistically significant, $\mathrm{F}(4,14)=10.56 ; \mathrm{p}<.001$, with $68 \%\left(\mathrm{R}^{2}\right.$ Adjusted $\left.=.680\right)$ of the total explained variance in total experience (Total experience) of tourists with their visit to Zagreb.

Concerning the individual contribution to the participation of the use of certain mobile applications in the overall tourism experience $\left(R^{2}\right.$ Change), the most important contribution of the applications (in the applied regression model - predictors) is: Voice Guide Zagreb, F $(1,16)=12,83$; p < .005, s $35 \%$ (.347) of the explained variance, Love Zagreb, F $(1,17)=4,81 ; \mathrm{p}<.005$, s $27 \%(.273)$ of the explained variance, Zagreb Be There, F $(1,16)=12,83 ; \mathrm{p}<.005$, sa $22 \%(.220)$ of the explained variance and Spotted By Lights, F $(1,14)=28,93 ; \mathrm{p}<.001$, sa $21 \%$ (.214) of the explained variance while the predictor Greetings from Zagreb has no significant participation. Based on the given indicators, it is possible to conclude that VGZ is important to visitors because of their exceptional practicality and personal surrogacy of personal travel guide and the most important instant information they need at any given time. Significant participation of the LZ application can be interpreted, among other things, due to its ability to provide a blogger with added value of credibility and contention of information.

The analysis also shows that the level of overall satisfaction of Zagreb's visitor is statistically significant; Love Zagreb $(\beta=.96, \mathrm{t}(19)=3.21, \mathrm{p}<.005)$, Voice Guide Zagreb $(\beta=.48, \mathrm{t}(16)=1.28, \mathrm{p}<.005)$ and Zagreb Be There $(\beta=-.38, \mathrm{t}$ $(19)=-1,89 \mathrm{p}<.005)$

As a response to the latest research objective $\mathrm{RO}_{3}$ - Identify if there are any possible negative circumstances in the use of mobile applications as a tourist destination for a smart destination, the respondents responded positively, pointing in particular to the possible additional technical burden and saturation of their mobile devices with new application installations, and are more inclined to give priority to primary and universal applications such as Facebook, Instagram, etc.

Like most research and this has its limitations. They relate, above all, to the specificity of the sample (s) and the time constraint of the research. Therefore, the most important recommendations for future research include: the selection of qualitatively different destinations (summer and winter holidays destinations, and other geographical areas) as a subject of research and longitudinal research on the same destination.

\section{CONCLUSION}

Rapid technological development in the field of tourism has led to a rapid growth of so-called smart tourist services in the destination, which lead to the creation and recognition of smart tourist destinations. As part of the application 
and use of numerous mobile applications in a tourist destination, it is important to distinguish and evaluate each individual function of the overall satisfaction and positive experience of its visitors in their use, as well as feedback useful for tourist service providers and destination management as a whole.

Following the aforementioned work, a targeted empirical study was carried out within the destinations visitors, on multiple locations and with a certain time dynamics, in the city of Zagreb, which was taken as a case study. In the data collection, a classical survey questionnaire was used, in which the respondents assessed the usefulness of the five most important mobile applications for their positive experience with visiting Zagreb. The results of the analysis of the collected data, which also represent the answers to the research goals, can be summarized as follows:

1. The usefulness of using all of the subjected mobile applications is statistically linked (correlated) with the degree of satisfaction by visiting the destination of Zagreb, as this relation is more significant in case of applications: Voice Guide Zagreb and Love Zagreb, which is a positive response to $\mathrm{RO}_{1}$.

2. In the overall experience of tourists, the most significant contributors are the Voice Guide Zagreb and Love Zagreb applications, while the Greetings from Zagreb application has no significant contribution. Based on the given indicators, it is possible to conclude that the Voice Guide Zagreb is important to visitors because of their exceptional convenience and personal surrogacy of the personal tourist guide and the most important instant information they need at the moment. Significant participation of the Love Zagreb application can be interpreted, among other things, due to its blogger's ability to provide added value to the credibility and contention of the information.

3. Respondents also expressed some of the negative circumstances of using the subjected applications, primarily because of the possible additional technical burden and saturation of their mobile devices with new application installations, and are more inclined to give priority to primary and universal applications such as Facebook, Instagram and others.

The significance of this research is to contribute to discovering new tools and techniques in managing the pleasure of destination visitors, through which realtime information about their behavior and preferences can be gained in terms of the concept of smart destination and, among other things, selective introduction of some applications to enhance the visitor experience and effectively manage a tourist destination as a whole. 


\section{LITERATURE}

1. Beritelli, P. 2011. Tourist destination governance through local elites -Looking beyond the stakeholder level. Cumulative Postdoctoral Thesis, St. gallen University, St. Gallen.

2. Boes, K., Buhalis, D. and Inversini, A. (2015). Conceptualising smart tourism destination dimensions. in Tussyadiah, I. and Inversini, A. (Eds), ENTER 2015 Proceedings, Springer-Verlag, Lugano and Wien.

3. Buhalis, D. \& Amaranggana, A. (2014). Smart tourism destinations. in Xiang, Z. and Tussyadiah, I. (Eds), Information and Communication Technologies in Tourism, Springer, Heidelberg, pp. 553-64

4. Buonincontri, P. and Micera, R. (2016). The experience co-creation in smart tourism destinations: a multiple case analysis of European destinations. Journal of Information Technology in Tourism, Vol. 16 No. 3, pp. 285-315.

5. Dieck, M.C. and Jung, T. (2018). A theoretical model of mobile augmented reality acceptance in urban heritage tourism. Current Issues in Tourism, Vol. 21 No. 2, pp. 154-174, doi: 10.1080/ 13683500.2015.1070801.

6. Gray, N.J. and Campbell, L.M. (2007). A decommodified experience? Exploring aesthetic, economic and ethical values for volunteer ecotourism in Costa Rica. Journal of Sustainable Tourism, Vol. 15 No. 5, pp. 463-482.

7. Gretzel, U., Sigala, M., Xiang, Z. and Koo, C. (2015a). Smart tourism: foundations and developments. Electronic Market (forthcoming)

8. Liberato, P., Alen, E. \& Liberato, D, (2018). Smart tourism destination triggers consumer experience: the case of Porto. European Journal of Management and Business Economics, Vol. 27 Issue: 1, pp.6-25, https://doi.org/10.1108/ EJMBE-11-2017-0051

9. Neuhofer, B., Buhalis, D. and Ladkin, A. (2012). Conceptualising technology enhanced destination experiences. Journal of Destination Marketing Management, Vol. 1 No. 1, pp. 36-46.

10. Pare, G. (2001). Using a positivist case study methodology to build and test theories in information systems: illustrations from four exemplary studies. available at: www2.hec.ca/gresi/documents/ cahier0109.pdf (accessed May 17, 2015).

11. Presenza, A., Micera, R., Splendiani, S. and Del Chiappa, G. (2014). Stakeholder e-involvement and participatory tourism planning: analysis of an Italian case study. International Journal of Knowledge Based Development, Vol. 5 No. 3, pp. 311-328. 
12. Tabachnick, B. G. i Fidell, L. S. (2007). Using multivariate statistics. Pearson/ Allyn i Bacon, Boston.

13. Wang, D., Park, S. and Fesenmaier, D. (2012). The role of smartphones in mediating the tourism experience. Journal of Travel Research, Vol. 51 No. 4, pp. 371-87

14. Wethner, H., Alzua-Sorzabal, A., Cantoni, L., Dickinger, A., Gretzel, U., Jannach, D., Neidhardt, J., Pröl, B., Ricci, F., Scaglione, M., Stangl, B., Stock, O. and Zanker, M. (2015). Future research issues in IT and tourism. A manifesto as a result of the JITT workshop in June 2014, Vienna. Journal of Information and Technology in Tourism, Vol. 15, pp. 1-15.

\section{UPRAVLJANJE ZADOVOLJSTVOM POSJETITELJA POMOĆU MOBILNIH DIGITALNIH ALATA I USLUGA ZA STVARANJE KONCEPTA PAMETNE DESTINACIJE}

Sažetak

Turizam je sustav koji neizostavno prati tehnološki napredak ostalih područja društvenog i gospodarskog života, pogotovo u domeni dostupnosti svih elemenata turističkog proizvoda koje nudi njegova osnovna jedinica - turistička destinacija. Slijedom sklonosti i potrebe korištenja mobilnih digitalnih alata i usluga od strane posjetitelja u svrhu boljeg snalaženja, sve se više nameće koncept tzv. pametne destinacije. Međutim, kako digitalne aplikacije sve više zasićuju svakodnevnicu i prijete saturaciji realnog i kvalitetnog života, nameće se potreba selektivnog pristupa i u domenu destinacijskog upravljanja kroz upravljanje iskustvom i zadovoljstvom posjetitelja.

Metodom usmjerenog anketnog upitnika provedeno je istraživanje na više turistički frekventnih lokacija u destinaciji, čiji je cilj bio, od pet najistaknutijih, istražiti važnost i participaciju pojedinačnih mobilnih aplikacija u unapređenju iskustva posjetitelja. Provedbom korelacijske i regresijske analize došlo se do rezultata, koje aplikacije najznačajnije participiraju u unapređenju iskustva posjetitelja. Značaj ovog istraživanja ogleda se u oblikovanju novog alata za adaptabilno i selektivno uvođenje novih mobilnih aplikacija u funkciji lakšeg snalaženja posjetitelja u destinaciji a time i učinkovitijeg upravljanja njihovim iskustvom.

Ključne riječi: pametna destinacija, mobilne aplikacije, zadovoljstvo i iskustvo posjetitelja, regresijska analiza 